\title{
Seasonal and multi-annual patterns of Phragmites australis decomposition in a wetland of the Adriatic area (Northeast Italy): a three-years analysis
}

\author{
M. Bertoli ${ }^{1}$, G. Brichese ${ }^{1}$, D. Michielin ${ }^{1}$, M. Ruzič ${ }^{1}$, F. Vignes ${ }^{2}$, A. Basset ${ }^{2}$ and E. Pizzul ${ }^{1, \star}$ \\ 1 University of Trieste, Department of Life Science, via Giorgieri 10, 34127 Trieste, Italy \\ ${ }^{2}$ University of Salento, Department of Biological and Environmental Science and Technologies, Via prov.le Lecce, Monteroni, \\ 73100 Lecce, Italy
}

Received July 27, 2015 - Revised January 8, 2016 - Accepted January 11, 2016

\begin{abstract}
Wetlands are one of the most biologically productive ecosystems, in which reedbeds of Phragmites australis are an essentially detritus-based system where litter decomposition is a fundamental process. This study represents a three year dataset describing cyclic trends of Phragmites australis leaf litter breakdown in a temporary and managed environment. For three years, 45 days field experiments were seasonally performed, using leaf bag technique within a large managed temporary pond (Natural Reserve of the Isonzo River Mouth, Northeast Italy), in order to analyze spatial and temporal variation in decomposition processes, to search for patterns on seasonal and inter-annual time scale and to infer the relevance of the main environmental features (physical and chemical) on decomposition dynamic. During the three years of analysis, decay rates $(k)$ ranges were $0.0066-0.0075$ days $^{-1}$ in autumn, $0.0108-0.0158$ days $^{-1}$ in spring and $k=0.0168$ days $^{-1}$ in summer. Average mass loss per day \% range was $0.97-1.31 \%$ in autumn, $1.12-2.04 \%$ in spring and $1.79-2.06 \%$ in summer. A well-defined seasonal cycle was observed through the study years as result of the drought-reflooding dynamic and the highest percentage (91.1\%) of the average mass loss per day \% variability was explained above all by rainfall, temperature and conductivity.
\end{abstract}

Key-words: Leaf bag / wetland / seasonal dynamic / temporary pond / decomposition rate

Résumé - Schémas saisonnier et pluriannuel de décomposition de Phragmites australis dans une zone humide de la région adriatique (Italie du Nord) : une étude de trois ans. Les zones humides sont parmi les écosystèmes les plus productifs, dont les roselières à Phragmites australis constituent un système basé essentiellement sur les détritus, où la décomposition de la litière représente un processus fondamental. Cette étude analyse un ensemble pluriannuel de données qui décrit les tendances cycliques relatives à la décomposition de Phragmites australis dans un milieu temporaire d'eau douce sujet à la gestion. Pendant trois ans, 45 jours d'expériences sur le terrain ont été effectués de façon saisonnière, en utilisant la technique du sac de feuilles dans un grand étang temporaire géré (Réserve Naturelle de l'embouchure de la rivière Isonzo, Italie du Nord), afin d'analyser les variations spatiales et temporelles dans les processus de décomposition, à la recherche de modèles à l'échelle temporelle saisonnière et inter-annuelle et d'en déduire la pertinence des principales caractéristiques environnementales (physiques et chimiques) sur la dynamique de la décomposition. Au cours des trois années d'analyse, les taux de décomposition ( $k$ ) étaient $0,0066-0,0075$ jours $^{-1}$ à l'automne, 0,0108-0,0158 jours ${ }^{-1}$ au printemps et $k=0,0168$ jours $^{-1}$ en été. La perte moyenne de masse par jour était de 0,97 à $1,31 \%$ en automne, 01,12 à $02,04 \%$ au printemps et de 1,79 à 2,06 \% en été. Un cycle saisonnier bien défini a été observé au cours des années d'études résultant de l'alternance assec-mise en eau. Le pourcentage le plus élevé $(91,1 \%)$ de variabilité de la perte de masse moyenne par jour a été expliqué surtout par les précipitations, la température et la conductivité.

Mots-clés : Paquets foliaires / dynamique saisonnière / milieu provisoire / taux de décomposition

\footnotetext{
^ Corresponding author: pizzul@units.it
} 


\section{Introduction}

Wetlands are one of the most biologically productive ecosystems (Dixon and Wood, 2003; Rolon and Maltchik, 2006; Mereta et al., 2012), performing many ecological functions, such as nutrient cycling (Bunn et al., 1999) and carbon storage (Adhikari et al., 2009). These environments are often dominated by macrophytes such as Phragmites, Typha, and Juncus (Kuehn and Suberkropp, 1998) which produce a considerable part of the organic material in these areas, and play an important role in the detritus food chain supplying an important nutrient source (van Dokkum et al., 2002; Eid et al., 2014). Reedbeds of Phragmites australis (Cav) Trin. Ex. Steud, especially, represent an essentially detritus-based system (Cowie et al., 1992; Komínková et al., 2000), which can be considered one of the most productive (Bedford, 2005). In this contest, litter breakdown appears as a fundamental process in the metabolism of wetlands (Webster et al., 1995; Wallace et al., 1997; Eid et al., 2014).

Plant breakdown rates in aquatic ecosystems have been found to be affected by internal factors, such as distinctive characteristics of the leaves (Kok et al., 1990; Canhoto and Graça, 1996), and by external environmental factors such as water temperature and salinity (Carpenter and Adams, 1979; Reice and Herbst, 1982; Vought et al., 1998; Sangiorgio et al., 2008a; Quintino et al., 2009), pH (Thompson and Bärlocher, 1989), nutrients (Elwood et al., 1981; Sharma and Gopal, 1982; Sangiorgio et al., 2008b), or regional characteristics (Sangiorgio et al., 2008a), such as climate (Murphy et al., 1998) and solar radiation (Denward and Tranvik, 1998). Litter breakdown has been widely studied in streams and rivers (Graça and Pereira, 1995; Diez et al., 2002; Menéndez et al., 2003; Pinna et al., 2003; Pinna et al., 2004; Sangiorgio et al., 2006), lakes (Gupta et al., 1996; van Dokkum et al., 2002) and transitional aquatic ecosystems, such as coastal lagoons or river mouths (Rossi and Costantini, 2000; Menéndez et al., 2004; Sangiorgio et al., 2004; Bayo et al., 2005; Sangiorgio et al., 2008a, 2008b). Otherwise, the decomposition of biomass on temporary freshwater wet sites with seasonally fluctuating water levels has received relatively little attention (Bedford, 2005; Völlm and Tannenberger, 2014). The water level in wetlands fluctuates seasonally due to natural processes, and at managed sites it can be deliberately manipulated to allow the access of personnel for vegetation cutting (Bedford, 2005), to enhance the mineralization of nutrients and to avoid conditions of hypoxia or anoxia (Street, 1982; Pizzul et al., 2008). In this context, it was deemed of interest to investigate the reed decomposition in a managed wetland carrying out analyses which were seasonally repeated over a long time period (three years), to search for cyclic temporal patterns on a large timescale.

The area selected for the present study was the Regional Reserve of the Isonzo River Mouth (Northeast Italy), which represents the northernmost wetland in the Mediterranean area and it is included in a Site of Community Importance (SCI IT3330005) and in a Special Protection Area (SPA IT3330005). A seasonal work including a first characterization of $P$. australis leaf litter breakdown was already been done in this area (Ruzič et al., 2013) and the analysis was carried on for another two years.
The aims of the present study are: (i) to analyze the spatial and temporal variation of $P$. australis decomposition processes in a large managed temporary pond subject to summer drought events; (ii) to search for temporal patterns on seasonal and annual timescale; (iii) to infer the relevance of the main extrinsic (environmental) chemical and physical features on plant detritus decay rates.

\section{Material and methods}

\subsection{Study area}

The study was carried out in a large temporary pond (30 ha surface) partially resulting from environmental recovery actions (Figure 1). The pond is enclosed by an embankment and it is supplied mostly by rainwater and by an artesian well. The western portion of the area is damp pasture, while the eastern portion is entirely constituted of a reedbed (Phragmites australis). The pond was of autumnal origin (temporary autumnal pools, sensu Wiggins et al., 1980), with a dry phase occurring from the late June until September, and a wet phase which begins in early autumn. The area features limnic to oligohaline basin waters (Stoch, 1995) with maximum depth ranging from 1.7 to $2.0 \mathrm{~m}$ (Stoch, 1995; Perco et al., 2006). As this area represents a wintering and stopover site for many bird species, management policy limits human access only to working personnel. However, the vegetation growth control is performed both passively (grazing of Camargue horses and periodically cattle) and actively (using machines). After mowing, plant material is usually removed in order to avoid anoxia conditions and reduce the amount of nutrients. The water level is controlled only with a flap sluice gate placed at the northwest side of the basin. This gate is occasionally open for a few days during summer (usually late July/mid-August) to ease the drought. The water level is monitored and managed for ecological reasons to avoid anoxic condition in the bottom sediments and to favor the remineralization of the nutrients (Street, 1982; Pizzul et al., 2008). A detailed description of the former hydrological condition is provided by Perco et al. (2006).

Five sampling sites were chosen for the present study (Figure 1) after considering characteristics such as water depth, vegetation coverage on the bottom and presence of vegetation nearby. The first was placed near the sluice side gate and close to the reedbed; the second site beside an islet without vegetation and the third beside a wooded islet, the fourth site was placed at the center of the basin and the fifth close to the reeds, where vegetation cover was observed.

\subsection{Leaf bag experiment}

Organic matter decomposition processes were studied by experimental field work on leaves of Phragmites australis, using the leaf bag technique (Petersen and Cummins, 1974). Leaf bags were prepared according to Basset et al. (2006) and as reported by Ruzič et al. (2013) and Bertoli et al. (2015) in previous investigations using leaf bags in the same area. 


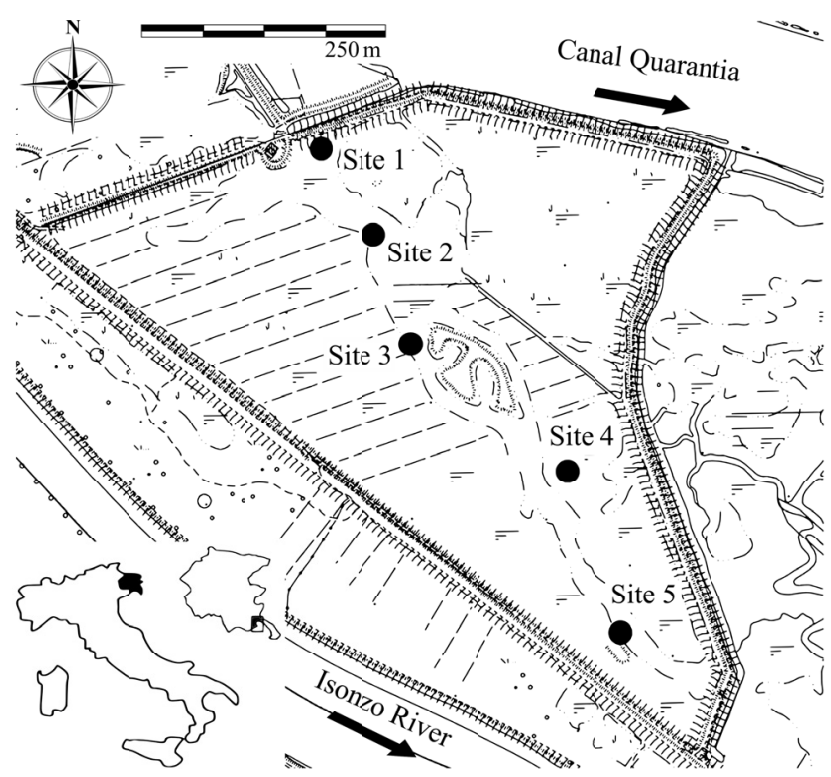

Fig. 1. The study area in the Natural Reserve of the Isonzo River Mouth (NE Italy) and position of the sampling sites (UTM coordinates: site $1 \mathrm{~N}$ 33T5067699.47 - E 383832.23; site $2 \mathrm{~N}$ 33T5067605.64 - E 383897.48; site 3 N 33T5067474.89 - E 383955.56; site $4 \mathrm{~N}$ 33T5067349.38 - E 384063.44; site $5 \mathrm{~N}$ 33T5067140.24 - E 384187.07).

At the beginning of autumn 2009 (last week of September) senescent leaves were collected in the pond under investigation, removing them from the shoots at least $30 \mathrm{~cm}$ above the water surface, avoiding apical leaves and those that had come in contact with water. We were careful to take only intact leaves without clear sign of decomposition from the top layer. After collection, leaves were air dried and stored in the dark at room temperature and low humidity until needed. Before use, leaves were cut into $10 \mathrm{~cm}$-long fragments (excluding the basal and apical parts), oven-dried to constant weight $\left(60{ }^{\circ} \mathrm{C}\right.$ for $\left.72 \mathrm{~h}\right)$ and then lots of $3.0000 \pm 0.0001 \mathrm{~g}$ dry weight were placed in $0.5 \mathrm{~cm}$ mesh bags. Oven-dried leaves were used in order to achieve initial conditions as uniform as possible (Bärlocher, 1997), to obtain standardized samples and to facilitate comparisons. Eventual bias as a result of the procedures used may have likely affected the absolute value of decay rates, as a systematic bias, but it will not have influenced the spatial and temporal patterns of reed decay rates, the analysis of which represents the principal objective of this study.

With the intention to reduce handling losses, leaf bags were kept separately in plastic containers and only the intact ones were used for the experiments, while those that showed a loss of material were immediately excluded. Thereby, in good approximation, we considered negligible the loss of material due to handling. During autumn $(10 / 27 / 2009 ; 10 / 19 / 2010$; $10 / 28 / 2011)$, spring $(4 / 1 / 2010 ; 4 / 1 / 2011 ; 3 / 27 / 2012)$ and at the beginning of June $(6 / 1 / 2010 ; 6 / 1 / 2011 ; 6 / 1 / 2012), 12$ leaf bags were submerged at each sampling site, placing them gently on the bottom sediment and tethering them to stones with strings, in order to prevent the loss. Leaf bags were then collected after 15, 30 and 45 days after submersion: at each sampling time, four leaf bags were retrieved from each sampling site, placed in separate polythene boxes containing pond water and rapidly brought to the laboratory. Here, leaves were gently washed to remove sediments and macroinvertebrate colonizers. Leaves from each bag were dried in an oven at $60{ }^{\circ} \mathrm{C}$ for $72 \mathrm{~h}$ and weighed $(x \pm 0.0001 \mathrm{~g}$ dry weight). Values of remaining mass at $t=15,30$ and 45 days of submersion were expressed as percentage, considering the initial weight at $t=0$ days $(3.0000 \pm 0.0001 \mathrm{~g}$ dry weight $)$ as $100 \%$. Winter sampling campaigns were not performed due to the presence of ice, which does not allow regular access to the study area. During summer, if drought occurred before the end of the experiment (45 days), leaf bags were considered lost and data were not included in the study.

We designed this multi-annual series of experiments with the aim to investigate spatial and temporal effects at seasonal scale, and to compare results obtained at this temporal scale along a three years period. The duration of the experiments (45 days) was chosen in order to limit analysis at seasonal level, and in order to allow comparisons among seasonal results.

\subsection{Physical and chemical parameters}

Depth was measured at each sampling time with a graduated rod. Conductivity $\left(\mathrm{mS} \mathrm{cm}^{-1}\right), \mathrm{pH}$, temperature $\left({ }^{\circ} \mathrm{C}\right)$ and dissolved oxygen $\left(\mathrm{mg} \mathrm{dm}^{-3}\right)$ were recorded using field meters (HI 9033 conductivity meter; HI 9125 pH/ORP meter; HI 9147 dissolved oxygen meter; all instruments are manufactured by Hanna Instruments Inc., Woonsocket, Rhode Island, USA). Values were measured approximately at mid-depth in the water column surrounding the leaf bags. Data were not collected during the drought. Seasonal rainfall data ( $\mathrm{mm}$ of fallen rain) were obtained by a weather station placed nearby the Reserve (Davis Vantage Pro 2 Plus, manufactured by Davis Instruments, Hayward, USA).

From October 2011 to July 2012, water samples were collected in sterile containers from the water column surrounding the leaf bags (approximately from mid-depth to the bottom), paying attention to avoid inclusion of sediment particles. Samples were filtered, frozen and brought to the laboratory. Here, concentrations of $\mathrm{NH}_{4}^{+}\left(\mathrm{mg} \mathrm{dm}^{-3}\right)$ was obtained measuring the absorbance at $625 \mathrm{~nm}$ obtained by reaction with phenol and hypochlorite in order to give an intensely blue solution of the so formed indophenols (Bolleter et al., 1961); $\mathrm{NO}_{2}^{-}\left(\mathrm{mg} \mathrm{dm}^{-3}\right)$ was evaluated by spectrophotometric measurement at $543 \mathrm{~nm}$ of colored derivative obtained from reaction with p-aminobenzene sulphonamide and N-(1-naphtil)etylendiamine (APHA, 1998); $\mathrm{NO}_{3}^{-}\left(\mathrm{mg} \mathrm{dm}^{-3}\right)$ concentration were measured at $220 \mathrm{~nm}$ with a correction for organic matter absorbance (Armstrong, 1963); finally, in order to obtain $\mathrm{PO}_{4}^{3-}$ $\left(\mathrm{mg} \mathrm{dm}^{-3}\right)$ concentrations, samples were allowed to react with a composite reagent containing molybdic acid, ascorbic acid, and trivalent antimony. The resulting complex polyacid is reduced to give a blue solution with the maximum extinction measured at $885 \mathrm{~nm}$ (Strickland and Parsons, 1972).

\subsection{Statistical analysis}

The percentage of the original mass remaining at the sampling times $(15,30$ and 45 days) were estimated and the 
decomposition rate was modeled as a negative exponential decay function, frequently used to describe decomposition (Olson, 1963; Petersen and Cummins, 1974):

$$
M_{t}=M_{0} \mathrm{e}^{-k t}
$$

where $M_{t}$ is the percent mass remaining at time $(t), M_{0}$ is the initial percent mass and $k$ is the decomposition rate. Percentage values of mass remaining were natural log-transformed (ln[\%mass remaining]) and ANCOVA was used to compare $k$-values as slopes of linear regression equations using time as covariate (Bärlocher, 2005; Zar, 1984). Data were checked for conformity to normality assumption with Shapiro-Wilks test and for conformity to assumption of variance homogeneity using C-Cochran's test (Cochran, 1941).

Percentage mass loss per day were estimated using the equation reported by Petersen and Cummins (1974). The two-way ANOVA and the Fisher Least Significant Difference (LSD-Fisher) post-hoc test were used to check spatial and temporal differences in the mass loss per day \% values (factors site-season and factors site-year; data were square root transformed: $x_{\text {transf }}=\sqrt{ } x$ ). Conformity to normality and variance homogeneity assumption were tested as mentioned above for percentage of original mass remaining data.

Finally, mean seasonal values of environmental abiotic factors were calculated for each sampling site and the relevance of abiotic characteristics as potential sources of variation in leaf decay rates was analyzed for each year using forward multiple stepwise regression analysis. Correlations among physical and chemical parameters were investigated using the Pearson product-moment correlation coefficient $(r)$. Abiotic data were transformed $\left(x_{\text {transf }}=\sqrt{ } x\right)$ to fulfill assumptions of normality. Conformity to normality and variance homogeneity assumption were tested with the same tests mentioned above.

ANOVA, multiple stepwise regression and correlations analysis were performed using StatSoft STATISTICA 7.1 (StatSoft, 2005); ANCOVA was performed using PAST 3.0 application (Hammer et al., 2001). Sites 3 and 5 were excluded from the comparisons involving autumn 2009 and summer 2012 respectively, because leaf bags were lost due to interference of animals (coypus and/or horses) living in the study area and to the summer drought, respectively. Finally, a summer dataset could only be obtained for 2012 owing to drawdown that interrupted the summer sequence of field experiments during the first and second years.

\section{Results}

\subsection{Leaf bag experiment}

Phragmites australis processing in the study area fits with negative exponential models in all the monitored seasons and temporal patterns were observed (Figure 2): reed leaves decay rates $k\left(\right.$ days $\left.^{-1}\right)$ differ significantly between autumn and spring every year, with lower values in autumn and higher in spring (Table 1, Figure 2a; $n=144, p<0.001$; Figure 2b, $n=160, p<0.001$; Figure $2 c, n=160, p<0.001)$; the highest $k$-value $\left(k=0.0168 \pm 0.0006\right.$ days $\left.^{-1}\right)$ was recorded during the summer of 2012. Inter-annual comparisons highlight that there are no differences among autumnal decay rates $(n=224$, $p=0.163)$, which ranged from $0.0066 \pm 0.0004$ days $^{-1}$ to $0.0075 \pm 0.0003$ days $^{-1}$ (Figure 2d); on the other hand, spring $k$-values differ significantly from year to year (Figure 2e, $n=$ $240, p<0.001)$ : the highest spring $k$-value was recorded during $2011\left(k=0.0158 \pm 0.0004\right.$ days $\left.^{-1}\right)$ and the lowest during $2012\left(k=0.0108 \pm 0.0004\right.$ days $\left.^{-1}\right)$. In addition, we observed that, even though the difference was significant, in the 20112012 period the gap between autumn and spring values was lower than the one observed for previous years (Figure 2c). It was observed that in autumn mean daily percentage of reed detritus weight loss ranged from $0.97 \%$ to $1.31 \%$, while in the spring periods values ranged between $1.12 \%$ and $2.04 \%$ (Figure 3). During summer 2012 daily mass loss range was $1.79-2.06 \%$. Spatial variation of reed decay among sampling sites was never significant, while decomposition of P. australis leaf bags always differed significantly on a temporal scale between autumn and spring (two-way ANOVA, $p<0.001$; Table 2) with the exception of the third year (Figure 3; LSD post hoc test; $p>0.77$ for the autumn-spring comparisons).

Values observed during the summer of 2012 were significantly higher than those recorded in the other seasons of the same year (Figure 3; Table 2) (LSD post hoc test; $p<0.05$ for all comparisons). Autumnal values of percentage mass loss per day do not differ among the years, while spring values always differ significantly (two-way ANOVA, $p<0.001$; Table 3), as observed for $k$-value.

\subsection{Physical, chemical data and nutrients}

Mean seasonal values of abiotic parameters and relative standard deviations are shown in Table 6. Variation of reed decomposition processes during the three-year period was analyzed taking into account the physico-chemical parameters measured during the whole study period (nutrients excluded) and during the last year (nutrient included).

Considering the whole study period, stepwise regression showed that $91.1 \%$ of the variability observed for the reed mass loss per day \% was explained by three abiotic characteristics (Table 5) (Stepwise multiple analysis: $r^{2}=0.911$; $\left.F_{3.29}=99.208 ; p<0.001\right)$ : rainfall $(\beta=-0.864)$, water temperature $(\beta=0.268)$ and water conductivity $(\beta=-0.222)$. Considering the last year dataset, which includes nutrients, stepwise regression showed that $91.9 \%$ of variance was explained by only two variables (Table 5) (Stepwise multiple analysis: $\left.r^{2}=0.919 ; F_{4.9}=45.513 ; p<0.001\right)$ : rainfall $(\beta=-0.660)$ and water temperature $(\beta=0.289)$. It was not possible to highlight significant contribution of the external nutrient concentration to the variation of daily mass loss. Rainfall was correlated with all physical and chemical monitored parameters, positively with depth $(r=0.423 ; n=33$; $p<0.02)$ and dissolved oxygen concentration $(r=0.449$; $n=33 ; p<0.01)$ and negatively with water temperature $(r=-0.663 ; n=33 ; p<0.001), \mathrm{pH}(r=-0.458 ; n=33$; $p<0.01)$ and conductivity $(r=-0.542 ; n=33 ; p<0.001)$. 

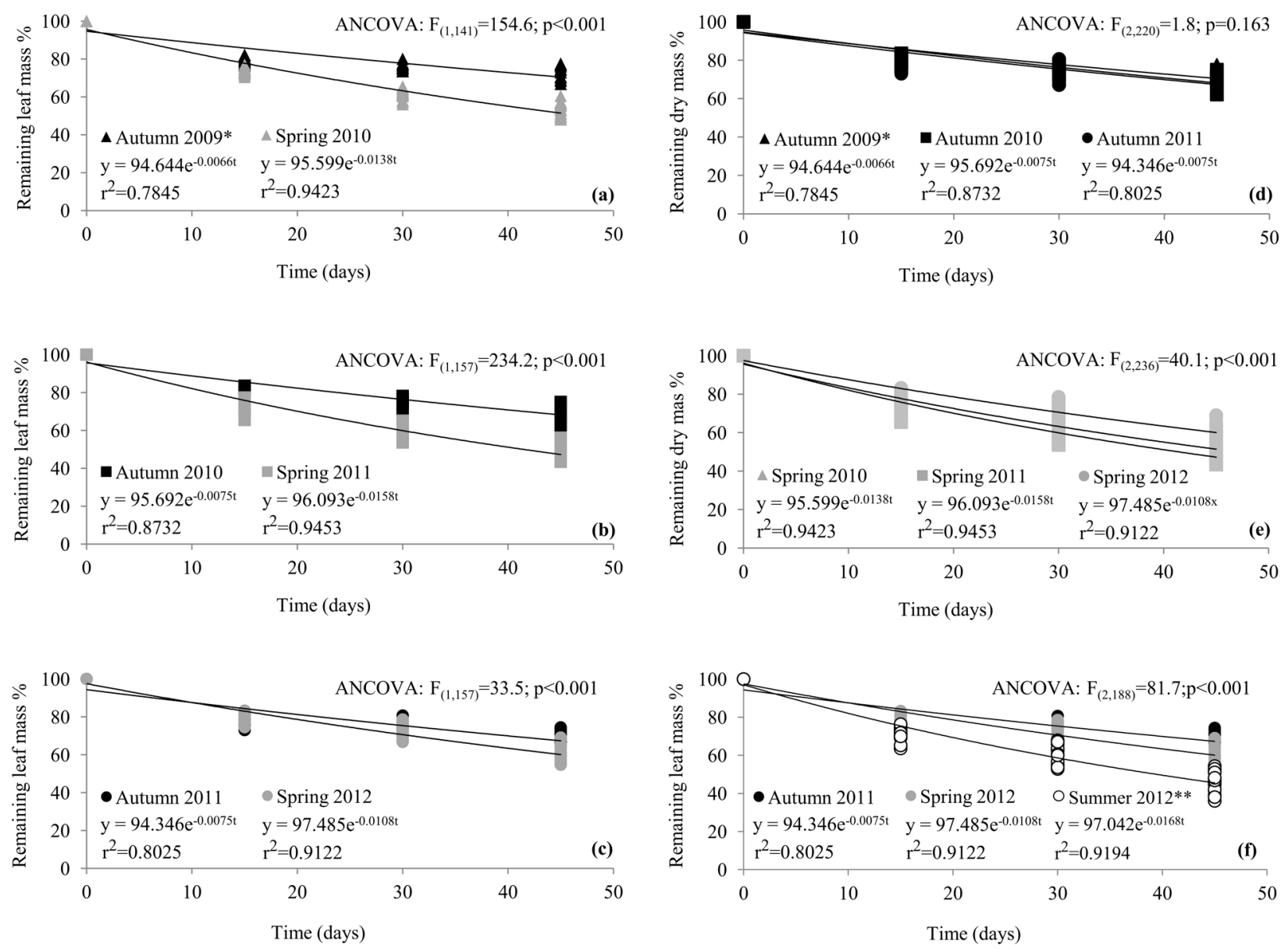

Fig. 2. Comparisons of $P$. australis leaf mass decay between successive seasons (a, b, c, f) and among homologous season of different years (d, e). The initial weight at $t=0$ days $(3.0000 \pm 0.0001 \mathrm{~g}$ dry weight) was considered as $100 \%$. (*): site 3 data not included; (**): site 5 data not included; (a): data and figure from Ruzič et al. (2013), modified.

Table 1. Mean values, standard deviations and sample sizes $(n)$ relative to the decomposition rates $(k)$ of the monitored seasons.

\begin{tabular}{|c|cc|cc|ccc|}
\hline & \multicolumn{2}{|c|}{$2009-2010$} & \multicolumn{2}{|c|}{$2010-2011$} & \multicolumn{3}{c|}{$2011-2012$} \\
\hline & Autumn & Spring & Autumn & Spring & Autumn & Spring & Summer \\
\hline$k$ & 0.0066 & 0.0138 & 0.0075 & 0.0158 & 0.0075 & 0.0108 & 0.0168 \\
\hline$S . D$. & 0.0004 & 0.0004 & 0.0003 & 0.0004 & 0.0004 & 0.0004 & 0.0006 \\
\hline$n$ & 64 & 80 & 80 & 80 & 80 & 80 & 64 \\
\hline
\end{tabular}

\section{Discussion}

\subsection{Leaf bag experiment}

The present study reports a multi-year continuous series of seasonal data regarding decomposition processes of Phragmites australis in a managed freshwater temporary environment. Our dataset is the result of sampling plans seasonally repeated for three consecutive years.

Previous seasonal investigations about $P$. australis breakdown processes have already been performed (Menéndez et al., 2001; Sangiorgio et al., 2004; Pinna et al., 2004; Sangiorgio et al., 2006) but the seasonal analyses were carried out for only one year. Furthermore, sampling designs extended for more than one year were employed by other authors, but work designs were planned as a single prolonged experiment without replication of separated seasonal activities (Hietz, 1992; Gessner, 2000; Asaeda et al., 2002; Bedford, 2005; Ágoston-Szabó et al., 2006); Asaeda et al. (2002) reported decomposition measures (made by Hietz, 1992) and model simulations for two consecutive years but the activities were carried out for 12 or 24 months consecutively; however, the authors reported a similar pattern for the two periods of analysis.

The decomposition rates $(k)$ of Phragmites australis leaf litter determined in the present study $(k=$ $0.0066-0.0075$ days $^{-1}$ in autumn; $k=0.0108-0.0158$ days $^{-1}$ in spring; $k=0.0168$ days $^{-1}$ in summer) for a large temporary pond of the Isonzo River Mouth Reserve are consistent with literature data (Table 4). However, direct comparisons 
M. Bertoli et al.: Knowl. Manag. Aquat. Ecosyst. (2016) 417, 14
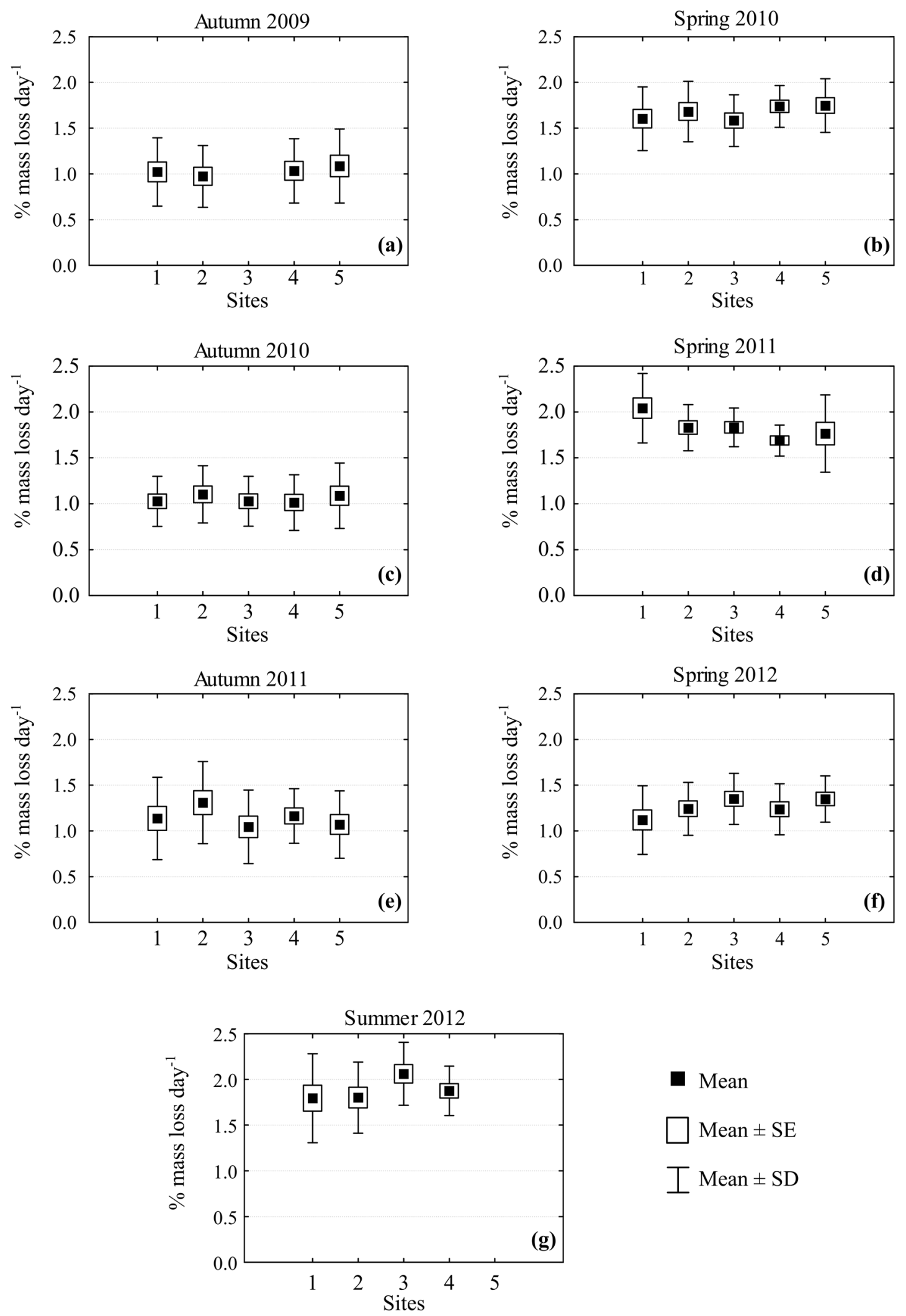

Fig. 3. Average mass loss per day (\%) observed at each sampling site during every monitored season. 
M. Bertoli et al.: Knowl. Manag. Aquat. Ecosyst. (2016) 417, 14

Table 2. Two-way ANOVA results for sites and seasonal periods of percentage loss per day values. Significance is highlighted in bold.

\begin{tabular}{|c|c|c|c|c|c|c|}
\hline Year & Source & Sum of Squares & d.f. & Mean Squares & $F$ & $p$-level \\
\hline \multirow{3}{*}{$2009-2010$} & Season & 2.644 & 1 & 2.644 & 18.820 & $<\mathbf{0 . 0 0 1}$ \\
& Site & 0.043 & 3 & 0.014 & 0.102 & 0.957 \\
& Site $\times$ Season & 0.016 & 3 & 0.005 & 0.038 & 0.990 \\
\hline \multirow{3}{*}{$2010-2011$} & Season & 4.859 & 1 & 4.859 & 50.860 & $<\mathbf{0 . 0 0 1}$ \\
& Site & 0.140 & 4 & 0.035 & 0.366 & 0.830 \\
& Site $\times$ Season & 0.109 & 4 & 0.027 & 0.285 & 0.884 \\
\hline \multirow{3}{*}{$2011-2012$} & Season & 5.498 & 2 & 2.749 & 18.015 & $<\mathbf{0 . 0 0 1}$ \\
& Site & 0.206 & 4 & 0.052 & 0.338 & 0.850 \\
& Site $\times$ Season & 0.472 & 8 & 0.059 & 0.387 & 0.919 \\
\hline
\end{tabular}

are generally difficult because individual investigations are carried out in different conditions, such as environments, time periods, hydrologic regimes, depths and decomposition rates could depend on geographical context (Sangiorgio et al., 2008a) and experimental conditions, such as different types of leaf bags mesh size (Bedford, 2005; Quintino et al., 2009).

The results of the present work highlight the following points: (i) temporal patterns of reed decomposition were observed, resulting in a clearly defined cycle; (ii) a high percentage of the variability in reed decomposition within the studied pond is explained by rainfall and, to a lesser extent, by water temperature and conductivity.

Following Petersen and Cummins (1974) classification $k$-values are medium $(0.005<k<0.010)$ during the autumnal seasons while becoming fast in the spring $(k>0.010)$, in agreement with the first observations reported by Ruzič et al. (2013) for the same studied pond (data included in the present study: Figure $2 \mathrm{a}$ ); then $k$-values likely increase further in the summer (data obtained during the last year support this assessment) and, finally, every year summer drought events bring the system back to the same decay rate (in autumn $0.0066<k<0.0075$ ). No significant spatial variation was observed, therefore we can conclude that the leaf litter decomposition proceeds homogeneously over the whole pond.

\subsection{Physical, chemical data and nutrients}

Similar seasonal leaf litter breakdown patterns, with lower decay rates during the fall-winter season in opposition to higher values recorded in the spring-summer period, have been already observed (Menéndez et al., 2003; Sangiorgio et al., 2004; Pinna et al., 2004). Temperature is one of the main driving factors in $P$. australis breakdown, positively influencing the decay rate values (Hanson et al., 1984; Webster and Benfield, 1986; Bedford, 2005; Sangiorgio et al., 2008a; Eid et al., 2014): water temperature increases microbial processing during decomposition and leaves served as a major energy source for invertebrates in aquatic ecosystems (Dudgeon, 1982); the role of microfungi and invertebrates in decomposition is well-known (Gessner and Chauvet, 1994; Graça, 2001; Hieber and Gessner, 2002; Menéndez et al., 2003).

In the pond under exam, water conductivity reflects salinity levels which could negatively influence $P$. australis processing (Mendelsshon et al., 1999; Sangiorgio et al., 2008a) and this effect could likely be mediated by the activity of microorganisms and benthic macroinvertebrates (Quintino et al., 2009). Several studies showed that increasing salinity correspond to decreasing microorganism activity (van Bruggen and Semenov, 2000; Rietz and Haynes, 2003; Sardinha et al., 2003; Muhammad et al., 2006; Wichern et al., 2006). The results described herein are in line with these findings: in fact, daily percentages of mass loss recorded during the spring of 2012 in correspondence of higher levels of conductivity (Table 4) did not differ from the autumnal values and are significantly lower than those observed in the previous years (Figure 3) and the gap between autumn and spring $k$-values was lower than the one observed for previous years (Figure 2c) with the spring value close to the limit between medium and fast decay rate classes reported by Petersen and Cummins (1974).

Annual variations in conductivity could be partially related with possible inputs of brackish water through the sluice side gate and largely related to the reduced rainfall observed in the 201-2012 period, which prevented new freshwater supply to the pond.

However, the drought/reflooding dynamic has probably played a major role in the variance of litter bag decomposition in temporary environments, as observed by Sangiorgio et al. (2006) in a riverine ecosystem subjected to drawdown. $P$. australis leaf litter decomposition in the studied pond is heavily influenced by the precipitation regime, which explains $84.9 \%$ of daily mass loss\% for the three year dataset and $87.2 \%$ of variation for the last year dataset which includes nutrients (Table 5). In fact, the monitored system was supplied by an artesian well and mostly by rainwater. Therefore, it is reasonable that significant differences in seasonal or annual rainfall could likely lead to variations in the temporal pattern of the drought-reflooding cycle and consequently to a change of the breakdown rates. Water level and inundation dynamics are known to have an influence on reed decomposition rates in wetlands (Völlm and Tannenberger, 2014) and the effects of extended drawdown periods were discussed by Bedford (2005), though using a different experimental leaf bag design. Metabolic activity of microbial decomposers is positively correlated with water availability and in presence of dry conditions the activity of decomposers is restricted, with consequent slowdown in the decay processes: flooding and/or drying events could be disruptive for invertebrates and their contribution to breakdown will therefore be limited (Bedford, 2005). In addition, colonization following reflooding is generally slow 
M. Bertoli et al.: Knowl. Manag. Aquat. Ecosyst. (2016) 417, 14

Table 3. Two-way ANOVA results for sites and seasons of different years of percentage loss per day value. Significance is highlighted in bold.

\begin{tabular}{|c|c|c|c|c|c|c|}
\hline Season & Source & Sum of Squares & d.f. & Mean Squares & $F$ & $p$-level \\
\hline \multirow{3}{*}{ Autumn } & Year & 0.133 & 2 & 0.066 & 0.402 & 0.673 \\
& Site & 0.024 & 3 & 0.008 & 0.047 & 0.986 \\
& Year $\times$ Site & 0.105 & 6 & 0.017 & 0.106 & 0.995 \\
\hline \multirow{3}{*}{ Spring } & Year & 2.853 & 2 & 1.427 & 15.463 & $<\mathbf{0 . 0 0 1}$ \\
& Site & 0.093 & 4 & 0.023 & 0.252 & 0.906 \\
& Year $\times$ Site & 0.311 & 8 & 0.039 & 0.421 & 0.899 \\
\hline
\end{tabular}

Table 4. Mean seasonal values and standard deviations of the physicochemical parameters (2009-2012) and nutrients (2011-2012) for the whole study area (Aut = autumn; Spr = spring; Sum = summer; Temp = water temperature; DO = dissolved oxygen; Cond = conductivity; $n=30$ in all cases, except for $(*)$, when $n=28)$.

\begin{tabular}{|c|c|c|c|c|c|c|c|c|}
\hline & & \multicolumn{2}{|c|}{$2009-2010$} & \multicolumn{2}{|c|}{$2009-2011$} & \multicolumn{3}{|c|}{$2011-2012$} \\
\hline & & Aut & Spr & Aut & $\mathrm{Spr}$ & Aut & Spr & Sum(*) \\
\hline \multirow{2}{*}{ Depth $(\mathrm{cm})$} & Mean & 30.2 & 36.4 & 37.9 & 24.3 & 33.8 & 27.8 & 12.6 \\
\hline & St. Dev. & 9.2 & 11.1 & 11.4 & 14.6 & 10.4 & 10.7 & 11.5 \\
\hline \multirow{2}{*}{ Temp $\left({ }^{\circ} \mathrm{C}\right)$} & Mean & 11.7 & 19.0 & 13.3 & 19.3 & 10.0 & 20.3 & 22.3 \\
\hline & St. Dev. & 3.4 & 4.2 & 1.9 & 2.5 & 5.2 & 2.6 & 1.6 \\
\hline \multirow{2}{*}{$\mathrm{pH}$} & Mean & 7.2 & 7.8 & 7.7 & 8.5 & 7.7 & 7.8 & 8.3 \\
\hline & St. Dev. & 0.5 & 0.6 & 0.6 & 0.4 & 0.3 & 0.3 & 0.7 \\
\hline \multirow{2}{*}{$\mathrm{DO}\left(\mathrm{mg} \mathrm{dm}^{-3}\right)$} & Mean & 4.5 & 4.0 & 5.1 & 2.3 & 8.5 & 2.4 & 3.2 \\
\hline & St. Dev. & 2.3 & 1.9 & 1.0 & 0.6 & 2.7 & 1.3 & 1.3 \\
\hline \multirow{2}{*}{ Cond $\left(\mathrm{mS} \mathrm{cm}^{-1}\right)$} & Mean & 2.6 & 2.7 & 2.1 & 3.0 & 3.7 & 4.9 & 6.5 \\
\hline & St. Dev. & 0.9 & 0.6 & 0.2 & 1.4 & 1.0 & 1.3 & 2.9 \\
\hline \multirow{2}{*}{ Rainfall (mm) } & Mean & 185.3 & 62.4 & 172.2 & 51.8 & 96.9 & 104.6 & 31.5 \\
\hline & St. Dev. & 3.8 & 26.8 & 65.3 & 21.1 & 103.5 & 39.1 & 28.2 \\
\hline \multirow{2}{*}{$\mathrm{NO}_{3}^{-}\left(\mathrm{mg} \mathrm{dm}^{-3}\right)$} & Mean & & & & & 0.32 & 0.31 & 0.24 \\
\hline & St. Dev. & - & - & - & - & 0.04 & 0.03 & 0.23 \\
\hline \multirow{2}{*}{$\mathrm{NO}_{2}^{-}\left(\mathrm{mg} \mathrm{dm}^{-3}\right)$} & Mean & & & & & 0.10 & 0.14 & 0.26 \\
\hline & St. Dev. & - & - & - & - & 0.03 & 0.07 & 0.31 \\
\hline \multirow{2}{*}{$\mathrm{NH}_{4}^{-}\left(\mathrm{mg} \mathrm{dm}^{-3}\right)$} & Mean & & & & & 0.17 & 0.61 & 0.30 \\
\hline & St. Dev. & - & - & - & - & 0.23 & 0.35 & 0.03 \\
\hline \multirow{2}{*}{$\mathrm{PO}_{4}^{3-}\left(\mathrm{mg} \mathrm{dm}^{-3}\right)$} & Mean & & & & & 0.02 & 0.03 & 0.19 \\
\hline & St. Dev. & - & - & - & - & 0.01 & 0.02 & 0.26 \\
\hline
\end{tabular}

(Bedford and Powell, 2005). Analyses on the macrobenthic communities within the study area carried out by Bertoli et al. (2015), simultaneously with the present work, showed how abundances of macrobenthic invertebrates were always lower during the fall than in the spring seasons. Our results are likely to be in line with these findings, considering also that observed $k$-values and daily mass loss \% measured in autumn (immediately after or during the completion of reflooding phase) do not show significant differences from year to year.

Breakdown decomposition rate could be also influenced by dissolved oxygen concentration (Chauvet, 1997), pH (Thompson and Bärlocher, 1989) or dissolved nutrients (Bärlocher and Corkum, 2003). In particular, concerning this last point, the contribution of the observed nutrients $\left(\mathrm{NO}_{3}^{-}\right.$, $\mathrm{NO}_{2}^{-}, \mathrm{NH}_{4}^{+}, \mathrm{PO}_{4}^{3-}$ ) to the daily mass loss \% variation was expected, due to extensive presence of migratory and nonmigratory birds in the study area, especially during the fallwinter seasons (Bertoli et al., 2015), and to the presence of horses and periodically cattle used for vegetation growth control. As part of a wetland, nutrient cycle is very complex within environments like the study area, and the changing redox potential largely influence the cycling of sensitive nutrients. The variability in concentration of nutrients and their availability could be influenced by the drying/re-flooding cycle. Moreover, management practices have to be considered, because water level control can be implemented through the opening of the sluice gate during summer, in order to favor mineralization of nutrients, avoiding hypoxia/anoxia (Street, 1982; Pizzul et al., 2008; Bertoli et al., 2015). As observed by Sangiorgio et al. (2008a), the daily reed mass loss could positively covary with reduced inorganic nitrogen compounds, while in the eutrophic system of the Danube Delta (Sangiorgio et al., 2008b), P. australis decay rates covaried positively with total phosphorus. Nevertheless, our results do not highlight the influence of nutrient concentrations in the breakdown dynamics for the studied area, even though the contribution of $\mathrm{NH}_{4}^{+}$to the daily mass loss variability tended to be significant $(\beta=-0.188$; $p=0.064)$. It is reasonable to assume that, on this temporal scale, the influence of rainfall was stronger than the influence of other abiotic features and it represented the main driving factor for the dynamic of the system under exam, together with temperature. Considering the spatial variability in decomposition dynamics, climate characteristics (expressed as evapotranspiration) is the best predictor of $k$-values at the global scale, while chemistry parameters explained a high percentage of 
Table 5. Stepwise multiple regression analyses between leaf mass loss per day (\%) and physico-chemical features measured over the three-year period (2009-2012; nutrients are excluded) and over the last year (2011-2012; nutrient are included). Significance is highlighted in bold (Rain = Rainfall; Temp = water temperature; Cond = conductivity).

\begin{tabular}{|c|c|c|c|c|c|c|c|}
\hline \multicolumn{3}{|c|}{$\begin{array}{c}\text { Physico-chemical dataset 2009-2012 } \\
\text { (nutrient excluded) }\end{array}$} & \multicolumn{3}{c|}{$\begin{array}{c}\text { Physico-chemical dataset 2011-2012 } \\
\text { (nutrient included) }\end{array}$} \\
\hline Variable & $r^{2}$ & $F$ & $p$-level & Variable & $r^{2}$ & $F$ & $p$-level \\
\hline Rain & 0.849 & 174.87 & $<\mathbf{0 . 0 0 1}$ & Rain & 0.872 & 81.83 & $<\mathbf{0 . 0 0 1}$ \\
\hline Rain, Temp & 0.877 & 6.90 & $\mathbf{0 . 0 1 3}$ & Rain, Temp & 0.919 & 6.47 & $\mathbf{0 . 0 2 7}$ \\
\hline Rain, Temp, Cond & 0.911 & 10.97 & $\mathbf{0 . 0 0 2}$ & & & & \\
\hline
\end{tabular}

Table 6. Leaf litter breakdown rates $\left(k\right.$ days $\left.^{-1}\right)$ for submerged litter of Phragmites australis observed in the study pond (Isonzo River Mouth Natural Reserve) compared with those reported in other studies.

\begin{tabular}{|c|c|c|c|c|c|}
\hline Ecosystem & $\begin{array}{l}\text { Length of the } \\
\text { experiment (days) }\end{array}$ & $\begin{array}{c}\text { Mesh } \\
\text { size }(\mathrm{mm})\end{array}$ & Period & $-k\left(\right.$ days $\left.^{-1}\right)$ & Reference \\
\hline $\begin{array}{l}\text { Freshwater pond } \\
\text { (North East Italy) }\end{array}$ & 45 & 5 & $\begin{array}{l}\text { Autumn 2009-2011 } \\
\text { Spring 2011-2012 } \\
\text { Summer 2012 }\end{array}$ & $\begin{array}{c}0.007-0.008 \\
0.014-0.016 \\
0.017\end{array}$ & Present study \\
\hline $\begin{array}{l}\text { Transitional waters } \\
\text { (Mediterranean area) }\end{array}$ & $30-40$ & 5 & Spring 2005 & $0.014-0.029$ & Sangiorgio et al. (2008a) \\
\hline $\begin{array}{l}\text { River basins subjected } \\
\text { to summer drought } \\
\text { (Sardinia, Italy) }\end{array}$ & 90 & 5 & $\begin{array}{c}\text { Spring-Summer } 1998 \\
\text { Winter-Fall 1998-99 }\end{array}$ & $\begin{array}{l}0.028 \\
0.009\end{array}$ & Pinna et al. (2004) \\
\hline $\begin{array}{l}\text { Freshwater lake } \\
\text { (Southern Italy) }\end{array}$ & 90 & 5 & $\begin{array}{c}\text { Autumn } 1998 \\
\text { Spring } 1999 \\
\text { Summer } 1999\end{array}$ & $\begin{array}{l}0.007 \\
0.013 \\
0.011\end{array}$ & \multirow{2}{*}{ Sangiorgio et al. (2004) } \\
\hline $\begin{array}{l}\text { Salt-marsh lake } \\
\text { (Southern Italy) }\end{array}$ & 90 & 5 & $\begin{array}{c}\text { Autumn } 1998 \\
\text { Spring } 1999 \\
\text { Summer } 1999\end{array}$ & $\begin{array}{l}0.006 \\
0.009 \\
0.010\end{array}$ & \\
\hline River delta (Danube) & 45 & 5 & Autumn 2005 & $0.009-0.0024$ & Sangiorgio et al. (2008b) \\
\hline Coastal lake (Egypt) & 150 & 5 & Apr-Sept 2003 & 0.0117 & Eid et al. (2014) \\
\hline $\begin{array}{l}\text { Reedbed wetlands } \\
\text { (North East England) }\end{array}$ & 599 & 5 & Jan 1995-Aug 1997 & 0.004 & Bedford (2005) \\
\hline $\begin{array}{l}\text { Natural fen } \\
\text { (Northern Germany) }\end{array}$ & $248-257$ & 0.3 & Sept 2010-May 2011 & 0.003 & Völlm and Tannenberger (2014) \\
\hline $\begin{array}{l}\text { Monomictic lake } \\
\text { (Netherlands) }\end{array}$ & 38 & 5 & $\begin{array}{l}\text { Summer } 1999 \\
\text { Winter } 1999\end{array}$ & $\begin{array}{l}0.055 \\
0.012\end{array}$ & Van Dokkum et al. (2002) \\
\hline
\end{tabular}

variance in $k$-values within a particular climatic region (Aerts, 1997; Sangiorgio et al., 2008a). Similarly, it is possible that climate factors, such as precipitation regime and temperature variations, are responsible for the pattern of leaf litter decomposition on large timescale.

\section{Conclusions}

The above study reports the seasonal data series from multiple years regarding breakdown processes of Phragmites australis within a temporary environment. This represents the principal value of this body of work, which results are consistent with the following conclusions: (i) P. australis reed leaf breakdown in the monitored large freshwater pond of Natural Regional Reserve of the Isonzo River Mouth shows clear seasonal patterns closely linked with the drought-reflooding cy- cle; (ii) these patterns repeat every year with some variations, depending chiefly on local climate factors (rainfall, temperature) and on conductivity variations due to structural features of the system.

The investigated pond provided an interesting scenario where reed decomposition processes could be more accurately studied and where the resilience of the system could be analyzed.

Finally, the results reported in the present work represent important information for the planning of management actions: regulation of the water level could be carried out to favor or slow down drought in managed ponds with direct consequences both on biotic and abiotic compounds, and indirect consequences on leaf litter decomposition rates in systems such as those monitored in the present study. 
Acknowledgements. We would like to thank Dr. Fabio Perco and the whole staff of the Reserve for the help. Thanks to Mr. Valter Mian (Municipality of Staranzano) for the data regarding rainfall, Dr. Ranieri Urbani and Dr. Paola Sist of the Department of Life Science of the University of Trieste for nutrients concentration measures.

\section{References}

Adhikari S., Bajracharaya R.M. and Sitaula B.K., 2009. A review of carbon dynamics and sequestration in wetlands. J. Wetl. Ecol., 2, 42-46.

Aerts R., 1997. Climate, leaf chemistry and leaf litter decomposition in terrestrial ecosystems: a triangular relationship. Oikos, 79, 439-449.

Ágoston-Szabó E., Dinka M., Némedi L. and Horvát G., 2006. Decomposition of Phragmites australis rhizome in a shallow lake. Aquat. Bot., 85, 309-316.

APHA, AWWA, WEF, 1998. Standard Methods for the Examination of Water and Wastewater, 20th edition. American Public Health Association, Washington, DC, 4-112/4-114.

Armstrong F.A.J., 1963. Determination of Nitrate in Water by Ultraviolet Spectrophotometry. Anal. Chem., 35, 1292-1294.

Asaeda T., Nam L.H., Hietz P., Tanaka N. and Karunaratne S., 2002. Seasonal fluctuations in live and dead biomass of Phragmites australis as described by a growth and decomposition model: implications of duration of aerobic conditions for litter mineralization and sedimentation. Aquat. Bot., 73, 223-239.

Bärlocher F., 1991. Fungal colonization of fresh and dry alder leaves in the River Teign. Nova Hedwig., 52, 349-357.

Bärlocher F., 1992. Effects of drying and freezing autumn leaves on leaching and colonization by aquatic hypomycetes. Freshw. Biol., $28,1-7$.

Bärlocher F., 1997. Pitfalls of Traditional Techniques When Studying Decomposition of Vascular Plant Remains in Aquatic Habitats. Limnetica, 13, 1-11.

Bärlocher F., 2005. Leaf mass loss estimated by litter bag technique. In: Graça M.A.S., Bärlocher F. and Gessner M. (eds.), Methods to study litter decomposition: A practical guide. Springer, Dordrecht, 37-42.

Bärlocher F. and Corkum M., 2003. Nutrient enrichment overwhelms diversity effects in leaf decomposition by stream fungi. Oikos, 101, 247-252.

Basset A., Sangiorgio F. and Sabetta L., 2006. Handbook for the application of body size descriptors to monitoring safety of transitional ecosystems. TW ReferenceNet - EU INTERREG III B Project 3B073. Management and sustainable development of protected transitional waters, University of Lecce, Lecce, $74 \mathrm{p}$.

Bayo M.M., Casas J.J. and Cruz-Pizarro L., 2005. Decomposition of submerged Phragmites australis leaf litter in two highly eutrophic Mediterranean coastal lagoons: relative contribution of microbial respiration and macroinvertebrate feeding. Arch. Hydrobiol., 163, 349-367.

Bedford P., 2005. Decomposition of Phragmites australis litter in seasonally flooded and exposed areas of a managed reedbed. Wetlands, 25, 713-720.

Bedford A.P. and Powell I., 2005. Long-term changes in the invertebrates associated with the litter of Phragmites australis in a managed reedbed. Hydrobiologia, 549, 267-285.

Bertoli M., Brichese G., Michielin D., Ruzič M., Vignes F., Basset A. and Pizzul E., 2015. Seasonal dynamics of macrozoobenthic community in the wetland of the Natural Regional Reserve of the Isonzo River Mouth, Northeast Italy: a three-years analysis. Ann. Ser. Hist. Nat., 25, 55-66.
Bolleter T., Bushman C.J., Tidwell P.W., 1961. Spectrophotometric Determination of Ammonia as Indophenol. Anal. Chem., 33, 592-594

Bunn S.E., Davies P.M. and Mosisch T.D., 1999. Ecosystem measures of river health and their response to riparian and catchment degradation. Freshw. Biol., 41, 333-345.

Canhoto C. and Graça M.A.S., 1996. Decomposition of Eucalyptus globulus leaves and three native leaf species (Alnus glutinosa, Castanea sativa and Quercus faginea) in a Portuguese low order stream. Hydrobiologia, 333, 79-85.

Carpenter S.R. and Adams M.S., 1979. Effects of nutrients and temperature on decomposition of Myriophyllum spicatum L. in a hard-water lake. Limnol. Oceanogr., 24, 520-528.

Chauvet E., 1997. Leaf litter decomposition in large rivers: the case of the River Garonne. Limnetica, 13, 65-70.

Cochran W.G., 1941. The distribution of the largest of a set of estimated variances as a fraction of their total. Ann. Eugen., 11, $47-52$.

Cowie N.R., Sutherland W.J., Ditlhogo M.O.M. and James R., 1992. The effects of conservation management of reed beds. II. The flora and litter disappearance. J. Appl. Ecol., 29, 277-284.

Denward C.M.T and Tranvik L.J., 1998. Effects of solar radiation on aquatic macrophyte litter decomposition. Oikos, 82, 51-58.

Diez J., Elosegi A., Chauvet E. and Pozo J., 2002. Breakdown of wood in the Aguera stream. Freshw. Biol., 47, 2205-2215.

Dixon A.B. and Wood A.P., 2003. Wetland cultivation and hydrological management in Eastern Africa: matching community and hydrological needs through sustainable wetland use. Nat. Resour. Forum, 27, 117-129.

Dudgeon D., 1982. An investigation of physical and biotic processing of two species of leaf litter in Tai Po Kau forest stream, New Territories, Hong Kong. Arch. Hydrobiol., 96, 1-32.

Eid E.M., Shaltout K.H. and Al-Sodany Y.M., 2014. Decomposition dynamics of Phragmites australis litter in Lake Burullus, Egypt. Plant Species Biol., 29, 47-56.

Elwood J.W., Newbold J.D. and Trimble A.F., 1981. The limiting role of phosphorus in a woodland stream ecosystem: effects of $\mathrm{P}$ enrichment on leaf decomposition and primary producers. Ecology, 62, 146-158.

Gessner M.O., 1991. Differences in processing dynamics of fresh and dried leaf litter in a stream ecosystem. Freshw. Biol., 26, 387-398.

Gessner M.O., 2000. Breakdown and nutrient dynamics of submerged Phragmites shoots in the littoral zone of a temperate hardwater lake. Aquat. Bot., 66, 9-20.

Gessner M.O. and Chauvet E., 1994. Importance of stream microfungi in controlling breakdown rates of leaf litter. Ecology, 75, $1807-1817$.

Graça M.A.S., 2001. The role of invertebrates on leaf litter decomposition in streams - a review. Int. Rev. Hydrobiol., 86, 383-393.

Graça M.A.S. and Pereira A.P., 1995. The degradation of pine needles in a Mediterranean stream. Arch. Hydrobiol., 134, 119-128.

Gupta M.K., Shrivastava P., Singhal P.K., 1996. Decomposition of young water hyacinth leaves in lake water. Hydrobiologia, 335, $33-41$.

Hammer Ø., Harper D.A.T. and Ryan P.D., 2001. PAST: Paleontological statistics software package for education and data analysis. Palaeontol. Electron., 4, 1-9.

Hanson B.J., Cummins K.W., Barnes J.R. and Carter M.V., 1984. Leaf litter processing in aquatic systems: a two variable model. Hydrobiologia, 111, 21-29.

Hieber M. and Gessner M.O., 2002. Contribution of stream detritivores, fungi, and bacteria to leaf breakdown based on biomass estimates. Ecology, 83, 1026-1038. 
Hietz P., 1992. Decomposition and nutrient dynamics of reed (Phragmites australis (Cav.) Trin. ex Steud.) litter in Lake Neusiedl Austria. Aquat. Bot., 43, 211-230.

IRSA-CNR and APAT, 2003. Metodi Analitici per le Acque, I.G.E.R. s.r.l., Roma, 1153 p.

Kok C.J., Meesters H.W.G. and Kempers A.J., 1990. Decomposition rate, chemical composition and nutrient recycling of Nymphaea $a l b a \mathrm{~L}$. floating leaf blade detritus as influenced by $\mathrm{pH}$, alkalinity and aluminum in laboratory experiments. Aquat. Bot., 37, 215227.

Kominkova D., Kuehn K.A., Busing N., Steiner D. and Gessner M.O., 2000. Microbial biomass, growth and respiration associated with submerged litter of Phragmites australis decomposing in a littoral reed stand of a large lake. Aquat. Microb. Ecol., 22, 271-282.

Kuehn K.A. and Suberkropp K., 1998. Decomposition of standing litter of the freshwater emergent macrophyte Juncus effusus. Freshw. Biol., 40, 717-727.

Kufel I. and Kufel L., 1988. In situ decomposition of Phragmites australis Trin. ex Steudel and Typha angustifolia L. Ekol. Pol., 36, 459-470.

Mendelssohn I.A., Sorrell B.K., Brix H., Schierup H., Lorenzen B. and Maltby E., 1999. Controls on soil cellulose decomposition along a salinity gradient in a Phragmites australis wetland in Denmark. Aquat. Bot., 64, 381-398.

Menéndez M., Martinez M., Hernàndez O., and Comín F.A., 2001. Comparison of Leaf Decomposition in Two Mediterranean Rivers: a Large Eutrophic River and an Oligotrophic Stream (S Catalonia, NE Spain). Int. Rev. Hydrobiol., 86, 475-486.

Menéndez M., Hernández O. and Comín F.A., 2003. Seasonal comparisons of leaf processing rates in two Mediterranean rivers with different nutrient availability. Hydrobiologia, 495, 159-169.

Menéndez M., Hernández O., Sanmartí N. and Comín F.A., 2004. Variability of organic matter processing in a Mediterranean coastal lagoon. Int. Rev. Hydrobiol., 89, 476-483.

Mereta S.T., Boets P., Bayih A.A., Malu A., Ephrem Z., Sisay A., Endale H., Yitbarek M., Jemal A., De Meester L. and Goethals P.L.M., 2012. Analysis of environmental factors determining the abundance and diversity of macroinvertebrate taxa in natural wetlands of Southwest Ethiopia. Ecol. Inform., 7, 52-61.

Muhammad S., Muller T. and Joergensen, R.G., 2006. Decomposition of pea and maize straw in Pakistani soils along a gradient in salinity. Biol. Fertil. Soils, 43, 93-101.

Murphy K.L, Klopatek J.M and Klopatek C.C., 1998. The effects of litter quality and climate on decomposition along an elevational gradient. Ecol. Appl., 8, 1061-1071.

Newell S.Y., 1996. Established and potential impacts of eukaryotic mycelial decomposers in marine/terrestrial ecotones. J. Exp. Mar. Biol. Ecol., 200, 187-206.

Olson J.S., 1963. Energy storage and the balance of producers and decomposers in ecological systems. Ecology, 44, 322-331.

Perco F., Merluzzi P. and Kravos K., 2006. The mouth of the Isonzo and Cona Island, Edizioni della Laguna, Mariano del Friuli (GO), $145 \mathrm{p}$.

Petersen R.C. and Cummins K.W., 1974. Leaf processing in a woodland stream. Freshw. Biol., 4, 343-368.

Pinna M., Sangiorgio F., Fonnesu A. and Basset A., 2003. Spatial analysis of plant detritus processing in a Mediterranean River type: the case of the River Tirso Basin, Sardinia, Italy. J. Environ. Sci., 15, 227-240.

Pinna M., Fonnesu A., Sangiorgio F. and Basset A., 2004. Influence of summer drought on spatial patterns of resource availability and detritus processing in Mediterranean stream sub-basins (Sardinia, Italy). Int. Rev. Hydrobiol., 89, 484-499.
Pizzul E., Guiotto S. and Moro G.A., 2008. Osservazioni sulle comunità macrozoobentoniche dell'Isola della Cona (Friuli Venezia Giulia, Nordest Italia). Ann. Ser. Hist. Nat., 18, 79-90.

Presley B.J., 1971. Techniques for analyzing interstitial water samples, part I: determination of selected minor and major inorganic constituents. In: Winterer E.L., Riedel W.R., Brönnimann P., Gealy E., Heath G., Kroenke L., Martini E., Moberly R. Jr., Resig J. and Worsley T. (eds.), Initial Reports of the Deep Sea Drilling Project. U.S. Government Printing Office, Washington D.C., Vol. 7, pp. 1749-1755.

Quintino V., Sangiorgio F., Ricardo F., Mamede R., Pires A., Freitas R., Rodrigues A.M. and Basset A., 2009. In situ experimental study of reed leaf decomposition along a full salinity gradient. Estuar. Coast. Shelf Sci., 85, 497-506.

Reice S.R. and Herbst G., 1982. The role of salinity in decomposition of leaves of Phragmites australis in desert streams. J. Arid Environ., 5, 361-368.

Rietz D.N. and Haynes R.J., 2003. Effects of irrigation-induced salinity and sodicity on soil microbial activity. Soil Biol. Biochem., 35, 845-854.

Rolon A.S. and Maltchik L., 2006. Environmental factors as predictors of aquatic macrophyte richness and composition in wetlands of southern Brazil. Hydrobiologia, 556, 221-231.

Rossi L. and Costantini M.L., 2000. Mapping the intra-habitat variation of leaf mass loss rate in a brackish Mediterranean lake. Mar. Ecol. Prog. Ser., 203, 145-159.

Ruzič M., Bertoli M., Pizzul E., Vignes F. and Basset A., 2013. Macrozoobenthic communities in the Regional Natural Reserve of Isonzo River Mouth (Northeast Italy): first results of a leaf bag technique study. Ann. Ser. Hist. Nat., 23, 7-16.

Sangiorgio F., Pinna M. and Basset A., 2004. Inter- and intrahabitat variability of plant detritus decomposition in a transitional environment (Lake Alimini, Adriatic Sea). Chem. Ecol., 20, 353-366.

Sangiorgio F., Fonnesu A., Pinna M., Sabetta L. and Basset A., 2006. Influence of drought and abiotic factors on Phragmites australis leaf decomposition in the River Pula, Sardinia, Italy. J. Freshw. Ecol., 21, 411-420.

Sangiorgio F., Basset A., Pinna M., Sabetta L., Abbiati M., Ponti M., Minocci M., Orfanidis S., Nicolaiou A., Moncheva S., Trayanova A., Georgescu L., Dragan S., Beqiraj S., Koutsoubas D., Evagelopoulos A. and Reizopoulou S., 2008a. Environmental factors affecting Phragmites australis litter decomposition in Mediterranean and Black Sea transitional waters. Aquat. Conserv. Mar. Freshw. Ecosyst., 18, 16-26.

Sangiorgio F., Dragan S., Rosati I., Teodorof L., Staras M., Georgescu L. and Basset A., 2008b. Decomposition of reed swamp detritus in the Danube Delta: a case study of four eutrophic systems. Transit. Waters Bull., 26-37.

Sardinha M., Müller T., Schmeisky H. and Joergensen R.G., 2003. Microbial performance in soils along a salinity gradient under acidic conditions. Appl. Soil Ecol., 23, 237-244.

Sharma K.P. and Gopal B., 1982. Decomposition and nutrient dynamics in Typha elephantine Roxb. under different water regimes. In: Gopal B., Turner R.E., Wetzel R.G. and Whigham D.F. (eds.), Wetlands Ecology and Management. National Institute of Ecology and International Sciences Publishers, Jaipur, 321-335.

Solórzano L., 1969. Determination of ammonia in natural waters by the phenolhypochlorite method. Limnol. Oceanogr., 14, 799-801.

StatSoft Italia srl, 2005. STATISTICA (sistema software di analisi dei dati), versione 7.1. www.statsoft.it.

Stoch F., 1995. Indagine ecologico faunistica sui popolamenti ad entomostraci di alcuni stagni di acqua salmastra dell'Isola della Cona (foce del Fiume Isonzo, Italia nordorientale). Gortania, Atti Mus. Friul. St. Nat. Udine, 16, 151-173. 
Street M., 1982. The use of waste straw to promote the production of invertebrate foods for waterfowl in manmade wetlands. In: Scott D.A. (ed.), Managing wetlands and their birds, Proceedings of the Third Technical Meeting on Western Palearctic Migratory Bird Management. International Waterfowl Research Bureau, Slimbridge, 98-103.

Strickland J.D.H. and Parsons T.R., 1972. A practical handbook of seawater analysis. Fishery Research Board, Canada, 310 p.

Thompson P.L. and Bärlocher F., 1989. Effect of pH on leaf breakdown in streams and in the laboratory. J. N. Am. Benthol. Soc., 8, 203-210.

van Bruggen A.H.C. and Semenov A.M., 2000. In search of biological indicators for soil health and disease suppression. Appl. Soil Ecol., 15, 13-24.

van Dokkum H.P., Slijkerman D.M.E., Rossi L. and Costantini M.L., 2002. Variation in the decomposition of Phragmites australis in a monomictic lake: the role of gammarids. Hydrobiologia, 482, 69-77.

Vought L.B., Kullberg A. and Petersen R.C., 1998. Effect of riparian structure, temperature and channel morphometry on detritus processing in channelized and natural woodland streams in southern Sweden. Aquat. Conserv. Mar. Freshw. Ecosyst., 8, 273-285.
Völlm C. and Tannenberger F., 2014. Shallow inundation favours decomposition of Phragmites australis leaves in a near-natural temperate fen. Mires and Peat, 14, 1-9.

Wallace J.B., Eggert S.L., Meyer J.L. and Webster J.R., 1997. Multiple trophic levels for a forested stream linked to terrestrial litter inputs. Science, 277, 102-104.

Webster J.R. and Benfield E.F., 1986. Vascular plant breakdown in freshwater ecosystems. Ann. Rev. Ecol. Syst., 17, 567-594.

Webster J.R., Wallace J.B. and Benfield E.F., 1995. Organic processes in streams of the eastern United States. In: Cushing C.E., Minshall G.W. and Cummins K.W. (eds.), Ecosystems of the World: v. 22. River and Stream Ecosystems. Elsevier, Amsterdam, 117-187.

Wichern J., Wichern F. and Joergensen R.G., 2006. Impact of salinity on soil microbial communities and the decomposition of maize in acidic soils. Geoderma, 137, 100-108.

Wiggins G.B.R., Mackay J. and Smith I.M., 1980. Evolutionary and ecological strategies of animals in annual temporary pools. Arch. Hydrobiol., 58, 97-206.

Zar J.H., 1984. Biostatistical Analysis, 2nd edition. Prentice-Hall International Inc., New Jersey, 718 p.

Cite this article as: M. Bertoli, G. Brichese, D. Michielin, M. Ruzič, F. Vignes, A. Basset, E. Pizzul, 2016. Seasonal and multi-annual patterns of Phragmites australis decomposition in a wetland of the Adriatic area (Northeast Italy): a three-years analysis. Knowl. Manag. Aquat. Ecosyst., 417, 14. 